\title{
Chapter 23 CONTROL OF INFECTIOUS DISEASES IN DAIRY CATTLE
}

Wendela Wapenaar, School of Veterinary Medicine and Science, University of Nottingham, UK Corresponding author: wendela.wapenaar@nottingham.ac.uk

Simon Archer, School of Veterinary Medicine and Science, University of Nottingham, UK John Remnant, School of Veterinary Medicine and Science, University of Nottingham, UK Alan Murphy, Minster Veterinary Practice, UK

\author{
Abbreviations \\ Al: Artificial insemination \\ BMSCC: bulk milk somatic cell count \\ BSE: bovine spongiform encephalopathy \\ bTB: Mycobacterium bovis (bovine tuberculosis) \\ BVD: Bovine viral diarrhoea virus \\ EBL: Enzootic Bovine Leukosis \\ ELISA: Enzyme Linked Immuno Sorbent Assay \\ EU: European Union \\ FAO: Food and Agricultural Organisation \\ FMD: Foot and Mouth Disease virus \\ IBR: Infectious Bovine Rhinotracheitis (Bovine Herpes virus-1) \\ MAP: Mycobacterium avium subspecies paratuberculosis \\ OIE: World Organisation for Animal Health \\ SCC: Somatic Cell Count \\ UN: United Nations \\ WHO: World Health Organisation
}

\section{Abstract}

This chapter describes developments of infectious disease control in the dairy cattle industry, and outlines recent research in this area. A risk analysis approach is presented as a framework for managing infectious disease at global and farm level. Disease hazards, and the release and exposure of these are discussed. The importance of disease detection, the use of diagnostic tests, their appropriate interpretation and surveillance are highlighted. The range of impacts of infectious disease on the dairy industry is described and guidelines to estimate and evaluate risks of infectious diseases are provided. In addition, the challenges around successful implementation and effective communication of risk management on dairy farms are reviewed.

Keywords: infectious disease control, dairy cattle, risk analysis, hazard, detection, surveillance, impact, risk estimation, risk management, implementation, farmer communication, veterinarian, animal health

\section{Contents}

1 Introduction

2 The impact of infectious disease

3 Principles of risk assessment and management

4 Hazard and risk identification

5 Risk assessment and evaluation

6 Risk management

7 Risk communication

8 Ensuring effective implementation

9 Trends in infectious disease control strategies

10 Conclusion 
11 Sources of further information and advice

12 References

\section{Introduction}

Animal tissues colonised with pathogenic organisms are said to be 'infected'. This may evoke a host response in an attempt to remove the 'causal' agent. Associated clinical signs are sometimes, but not always, visible in the live animal. Commonly infection is subclinical, meaning no observable change occurs in the host, despite the potential for onward disease transmission. Infectious diseases in dairy cattle pose threats to food security, food safety, national economies, biodiversity and the rural environment. Challenges, such as climate change, regulatory developments, changes in the geographical concentration and size of livestock holdings, and increasing trade change the impact of dairy cattle diseases and the ways in which they can be controlled. New infections of environmental origin are inherently local, yet spread of infection between cattle can potentially be global.

Responsibility for control may reside with governments or individual farmers, yet the principals of disease control are universal.

This chapter starts by reviewing the impact of infectious disease. It then discusses basic principles of risk assessment and management before going to review some of the key steps: hazard and risk identification, followed by risk assessment and evaluation, and concluding with risk management. It also discusses the key role of effective communication, issues in ensuring effective implementation and trends in infectious disease control strategies.

An example farm is used to illustrate some of the key issues in disease control. The farm is a 200 cow dairy herd in the UK. On this farm, producing 7,800 kg of milk per cow per year, the cows are housed from November to March and graze in the farms fields for the rest of the year. The herd calves all year round. The farm breeds its own replacements. Heifers are contract reared off-site from eight weeks of age, and return to the farm approximately 4 weeks before calving. A bull is bought approximately every 3 years to breed cows not pregnant after 3 to 6 Al attempts. The farm is surrounded by arable land on three sides, fields on the remaining side border an extensive beef and sheep farm.

It is a family run farm, employing 2 casual workers during busy times. The farmer's wife and children help out with milking on a regular basis. The farm uses a contract foot-trimmer and contractors assist with forage and slurry management. The farmer wants to expand to a 300 cow herd. The farmer's business goal is to be most profitable by optimizing herd health and production. To stay informed, he reads the local farming press, and attends farmer discussion groups. A farm consultant visits monthly to discuss farm progress, mainly focussing on nutrition. An agricultural accountant visits monthly to discuss finance. A veterinarian visits the farm once a month for a routine visit, mainly focussing on fertility. The farmer is in need of time to organise and care for his elderly parents. The farmer's eldest child is due to return from a year working on dairy farms in New Zealand, via a trip backpacking in South East Asia.

The herd is currently tested for bTB every four years as part of a government programme. The farmer vaccinates breeding cattle against BVD following detection of BVD in youngstock three years previously. A quarterly bulk tank milk ELISA test is conducted to identify antibodies to IBR and Leptospira serovar Hardjo (Leptospirosis). The last four tests were low positive for IBR and negative for Leptospirosis. Individual cow milk ELISAs for MAP are carried out to meet milk buyer requirements. In the latest test report, six cows were identified as MAP-positive (following two consecutive positive ELISA results) and 10 cows were classified as 'inconclusive' (tested ELISA positive once). The farm is on monthly milk recording, and has basic data collection in place, including Al and treatment records that are entered into computer software. 


\section{The impact of infectious disease}

The impact of infectious diseases in dairy cattle need consideration in its full extent; this encompasses impacts on:

- animal welfare

- animal productivity

- public health

- trade

- Society

Each of these need attention when performing an impact assessment on an individual farm.

The impact of infectious disease on animal welfare can present itself in direct and indirect ways. Dependent on the pathogen, animals can experience stress, pain and fear as a consequence of disease and its management. Indirectly, animal movement restrictions dictated by government disease control programs can lead to housing problems due to increasing stocking densities when animals cannot leave the farm. Slaughter programs in response to a disease outbreak need to assure a humane death for animals killed on the farm to ensure animal welfare.

Animal diseases lead to mortality and reduced productivity in dairy herds worldwide, causing substantial economic losses. Diseases may affect dairy farm productivity through:

- lowered milk yield

- reduced milk quality

- increased statutory or voluntary culling

- increased adult cow mortality

- reduced feed conversion

- delayed age at first calving

- reduced fertility

- reduced weight gain

- reduced market value

Milk production can be profoundly reduced in cows with clinical disease. The duration of acute clinical syndromes can be short, but the effects of the disease may persist throughout the entire lactation (Archer et al., 2013). Disease during early lactation may reduce peak milk yields and therefore contribute to lower total lactation yields. The effects of disease on productivity can be direct (such as mastitis causing a profound reduction in milk yield) or indirect (IBR infection leading to reduced feed intake, thus causing reduced milk yield). The best documented direct effect is the effect of mastitis on milk yield. A single case of clinical mastitis can result in a milk yield loss of 300$400 \mathrm{~kg} /$ lactation, with variations ranging from negligible to $1,050 \mathrm{~kg}$. Mastitis during early lactation is associated with higher losses $(450-550 \mathrm{~kg}$ ) than cases seen later in lactation. Probabilistic sensitivity analysis carried out by Down et al. (2013) suggests that, when seeking to minimize the economic impact of clinical mastitis in dairy herds, great emphasis should be placed on the reduction of pathogen transmission from cows with clinical mastitis to uninfected cows.

Production losses resulting from endemic disease can be considerable; a Canadian study investigating the effect of BVD, Neosporosis ( $N$. caninum) and MAP demonstrated that cows in BVDseropositive herds had reductions in 305-day milk yield, fat, and protein of 368, 10.2, and $9.5 \mathrm{~kg}$, respectively, compared with cows in BVD-seronegative herds. MAP-seropositivity was associated with lower 305-day milk yield of $212 \mathrm{~kg}$ in multiparous cows compared with MAP-seronegative multiparous cows. $N$. caninum seropositivity in primiparous cows was associated with lower 305-day milk yield, fat, and protein of 158, 5.5, and $3.3 \mathrm{~kg}$, respectively, compared with $N$. caninum- 
seronegative primiparous cows (Tiwari et al.,2007). A follow-on study assessed the impact of MAP and found an average Canadian dairy herd lost CA\$2992 annually due to MAP, or CA\$49 per cow per year (Tiwari et al., 2008). A study to determine costs due to four endemic infectious diseases in Canada (MAP, BVD, N. caninum and EBL found total annual costs for an average, infected, 50 cow herd to be CA\$2472 for MAP; CA\$2421 for BVD; CA\$2304 for N. caninum and CA\$806 for EBL. A sensitivity analysis showed the largest effect on costs was due to the effect on milk yield (Chi et al., 2002).

Diseases that delay or prohibit oestrus expression or conception have a negative effect on herd productivity by prolonging the time cows spend in lower-producing stages of lactation, by reducing the number of offspring for replacements or for sale, and by increasing the likelihood the animal will be culled prematurely. For example, the likelihood of conception was reduced by $15 \%$ for cows that experienced metritis. A Canadian study demonstrated that EBL-seropositive cows had a higher risk of prolonged calving interval in first lactation cows compared with EBL-seronegative cows. $\mathrm{N}$. caninum-seropositive cows had a 1.27 times higher odds of having a calving interval $>484$ days compared to N. caninum-seronegative cows. Also, an interaction between N. caninum and BVD was observed with respect to first service to conception interval, with odds ratios of 0.64 and 1.06 for $N$. caninum-seropositive cows (compared to $N$. caninum-seronegative cows) in BVD-seronegative and BVD-seropositive herds, respectively (VanLeeuwen et al., 2010).

In the dairy industry reduced weight gain is important when rearing heifers or bull calves. Unsurprisingly, studies have found that diseased animals gain weight more slowly than equivalent disease-free animals. Furthermore, diseased animals may have lower market value either due to visible lesions or indirect changes in appearance or body conformation which make them less attractive to buyers. True market value of final products may be altered due to changes in the ratio of meat to fat or to bone. The value of meat or offal from cull cows may also be reduced due to pathological changes caused by infectious pathogens such as Fasciola hepatica or Echinococcus granulosus. Presence of lesions of a zoonotic disease renders the carcase partially or totally unfit for consumption. Generalised systemic illness may also lead to condemnation of an entire carcase. Diseases which affect the skin, such as warble fly infestation may reduce the market value of hides. The costs of culling can be offset by a financial return if the animal can enter the food chain. Voluntary culling is part of a cost effective herd replacement strategy, whereas involuntary culling is undesirable. An inadequate replacement strategy can leave an empty cubicle space on the farm which increases fixed costs per litre of milk produced. The two most important services provided by cattle in the developing countries are traction and manure production, and disease may reduce the supply of both of these.

Many dairy cattle production diseases do not result in death, but reduce the production efficiency. A large proportion of cattle that are culled from a dairy herd are considered involuntary culls (driven by disease or injury) rather than for reasons of low production. The premature removal of a cow from the herd reduces her lifetime milk yield and incurs disposal costs for the carcase. The impact of a disease on productivity is dependent on many others factors such as exposure of the pathogen involved; introduction of the same pathogen into a naïve herd will have much greater impact compared to the transmission of this pathogen already present in the herd. Factors such as these make it difficult to draw sweeping conclusions with regards to the cost of disease on a farm, although some of the referenced studies give an indication of potential effects of pathogens on productivity. It remains crucial for veterinarians to discuss potential productivity losses with their client on an individual farm basis.

Approximately $75 \%$ of recent emerging human diseases have emerged from an animal source. The route to exposure to infectious pathogens is different between developed and developing countries; 
in the UK the use of unpasteurised milk is gaining popularity within certain parts of the population, increasing the risk of disease although pasteurised products are widely available. Human health risks, such as Lyme disease (2000 human cases/year in the UK) or E.coli at farm visitor attractions highlight the tension between recreational and productive use of the countryside. Other examples of zoonotic diseases which have substantial health impacts on the human population are BSE, Q-fever (Coxiella burnetti) (Porter et al., 2011) and Brucellosis. In developing countries the route to exposure is more difficult to control due to intensive contact between pastoral farmers and their cattle, and the limited opportunities to improve food safety, such as pasteurization. A livestock-human brucellosis transmission model (Zinsstag et al., 2005) was linked to a livestock productivity analysis to evaluate the impact of a planned 10-year livestock mass vaccination campaign to determine the cost-effectiveness, expressed as cost per DALY (disability adjusted life year) averted. The conclusion was that if the costs of livestock vaccination were allocated to all sectors in proportion to the benefits, the intervention might be profitable and cost effective for the agricultural and health sectors (Roth et al., 2003).

Particularly in developing countries the major effect of animal disease on human wellbeing is through a reduced supply of high quality protein, which means a reduced supply of milk for young children. Cattle products are also important sources of other nutrients, notably minerals and vitamins, and diseases can both reduce the total supply of animal products and modify the composition of animal products in ways which reduce their nutritional value.

Even for infectious diseases of primarily viral origin, such as bovine respiratory disease, antimicrobials are often used as treatment, since secondary bacterial pathogens may be involved. Whilst there is currently limited evidence that the use of antimicrobials in farm animals is a significant contributor to the development of antimicrobial resistance in the human population, there is significant public interest in the prudent use of antimicrobials in veterinary medicine, and veterinarians must prescribe responsibly if this privilege is to remain. To this end, reliance on treatment with antimicrobials is unlikely to be sustainable; therefore, the control and prevention of infectious disease in cattle is paramount.

The occurrence of trade-restricting diseases impact both livestock farmers in the developed and developing world by marginalizing them from higher-price livestock markets and restricting their capacity for value-added trade. The global epidemiology of FMD is almost a mirror image of the global economic structure:

- FMD-free group: equivalent to high-income, industrialized zones

- FMD control regions: mainly middle-income, semi-industrialized countries characterized by medium to high FMD-control activity; South America is the most prominent of these regions

- FMD endemic group: generally among the least-developed countries, some of which have a high livestock density

The socio-economic trade effects of disease and subsequent disproportional government support at a national level in the developed world are illustrated by the FMD outbreak in the UK in 2001: a 3 billion GBP loss was estimated for the public sector and 5 billion GBP to the private sector, and losses on tourism and local businesses were larger than losses to farming. However, culled-out farmers received financial compensation whereas small rural businesses did not.

The effect of an export ban can be significant in developed as well as developing countries. For example, for Somalia, a significant and longstanding exporter of live animals to Kenya and the Gulf region, the effect of an export ban of cattle in 1998-2000 due to Rift Valley Fever was devastating; exports decreased by 2 million head which equated to approximately US\$100 million to individuals and communities in the region. During the ban, it was estimated that the price of cattle fell by $65 \%$. In terms of absolute loss of income, the poor were less affected since they sell fewer numbers of 
animals, but they probably endured greater hardship than the rich because the ban prevented them from selling the few animals they need to sell to survive.

At the farm level trade can also be impeded by infectious diseases due to its effect on the value of its produce; a high SCC in milk will be penalized by the milk processor, who will pay less or will refuse to process the milk. Milk from cattle treated with antimicrobials cannot be sold into the food chain during the milk withdrawal period, and the presence of infectious disease on the farm will reduce the likelihood of farmers to sell stock or produce.

In the UK, BSE damaged public confidence in food safety and undermined the food industry and British agriculture which faced a decade-long ban on beef exports. In addition, the government's lack of transparency, its handling of the scientific uncertainty that had surrounded BSE aetiology and government promotion of the interests of farmers over the public interest, severely damaged public trust in policy making. Efforts to harmonize trade within the European Union and to reform the common agricultural policy by reducing international trading barriers has led to an increase in the scale and frequency of international livestock movements, and the reappearance of FMD in several countries that were formerly free of the disease (Woods, 2011).

Infectious disease outbreaks, such as FMD, Bluetongue and bTB, emphasize that maintenance of a 'disease-free' status when the disease occurs elsewhere is risky and difficult to control. A collaborative effort in supporting developing countries or other farmers to control infectious disease will benefit others already free from disease. Political support is present in some cases but is sometimes hampered by the economic advantage a 'disease-free' country has over not 'diseasefree' countries when exporting their produce.

Particularly in developing countries animals serve functions far beyond utilitarian roles. While these are not strictly economic in nature, they are vital functions which should be included in any consideration of the significance of animal disease. Livestock sales are instrumental for expenditures such as school fees, to support development of their children via education.

How would the impact assessment apply to our example farm? It is difficult to assess the effect of one infectious disease on productivity but the knowledge that BVD is present make it likely that reproductive and youngstock health performance would increase when this disease is eradicated. If BVD were eradicated, biosecurity precautions should be stepped up to minimize the risk of reintroducing disease, and costed into the programme. It is important to investigate culling rates on the farm, as they may be increased due to infectious disease.

With the cattle industry supporting BVD eradication in the UK it is important to consider the decrease in market value an animal from this farm may have. In Europe, milk processors and retailers are becoming more involved in quality control of their products and the consequences this may have on this farm where endemic disease are present is worth discussing with the farmer. Because the farmer is considering selling heifers abroad, it is important to review export requirements, where often a negative antibody test is required to permit export. Also the use of vaccines is often not permitted, as it interferes with the detection of naturally acquired antibodies. Marker vaccines are available for IBR to facilitate international trade of cattle.

Social influences are often unmentioned but can be important drivers for farmers to control diseases such as BVD. They often want to be perceived as 'good' farmers, and their cattle being disease-free contributes to that. 


\section{Principles of risk analysis and management}

Infectious agents can transmit to susceptible cattle through a variety routes, particularly when population density is high, resistance is compromised, or pathogens are particularly virulent. Many infectious agents can survive in the environment, and this reservoir can overwhelm host defences if hygiene is poor. We acknowledge the importance of maintaining environmental hygiene and animal immunity through adequate nutrition and husbandry, but focus this Chapter on the principals of reducing the risk of infectious pathogen transmission by applying a risk analysis approach (Figure 1) using the OIE and FAO framework (FAO, 2016). Hazard identification is the process of identifying the pathogenic agents which could potentially be introduced. Risk assessment is the evaluation of the likelihood and the biological and economic consequences of entry, establishment or spread of a pathogenic agent. Risk management is the process of identifying, selecting and implementing measures that can be applied to reduce the level of risk. Risk communication is the interactive exchange of information on risk among risk assessors, risk managers and other interested parties.

Figure 1. The four components of risk analysis

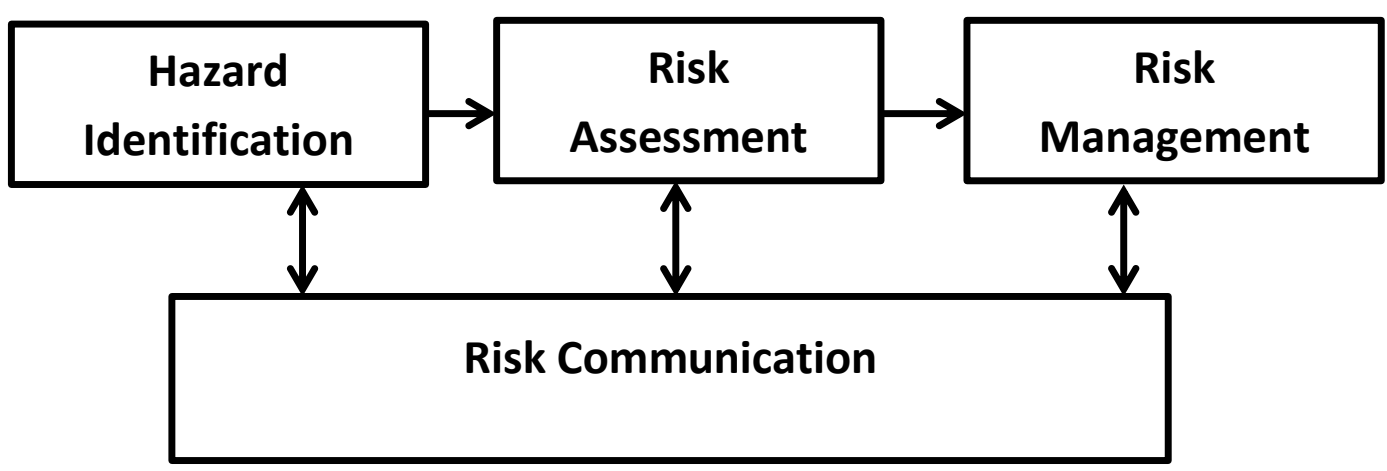

An infectious disease is controlled when the incidence rate at which new cases occur in susceptible individuals is less than the rate at which infected individuals are removed, by recovery or death of the animal. The threshold for many epidemiology models is the basic reproduction number $\mathrm{R}_{0}$, which is defined as the average number of secondary infections produced when one infected individual is introduced into a host population where everyone is susceptible. For many epidemiology models, an infection can get started in a fully susceptible population if and only if $R>1$. Thus the basic reproduction number $\mathrm{R}$ is often considered as the threshold quantity that determines when an infection can invade and persist in a new host population.

Endemic diseases occur at a steady state in a population, measured by the prevalence, the proportion of individuals infected. An important concept in infectious disease management is to determine an acceptable prevalence on economic and welfare grounds. For some diseases that are considered exotic, any presence is unacceptable. Eradication is a special case of control where active measures are taken to eliminate disease.

Managing infectious disease incurs a cost and the consequences of infectious disease are also costly. This infectious disease cost is often difficult to comprehend; as insidious production losses may be challenging to demonstrate. Risk analysis is a process to balance the costs of disease control with the costs of the consequences, in order to aid decision making around infectious disease management. The use of the risk analysis framework will demonstrate the logic of the steps involved, and highlight the complexities when managing endemic infectious diseases. 


\section{Hazard and risk identification}

Hazards are items that may cause harm. In the context of infectious diseases, these are the causal pathogens themselves. It is important to appreciate the difference between risks and hazards. Hazards can cause harm, conditional on other events. Risks are a measure of how likely it is that harm will occur in a particular circumstance. For example, IBR-virus is a hazard for a naïve herd, but may only become a significant risk if a farmer plans to purchase replacement heifers from an IBRpositive herd or one of unknown health status.

A non-exhaustive list of hazards that could cause harm to cattle is provided in Table 1 . It is beyond the remit of this Chapter to discuss the specific biology of each infectious pathogen. However, it is acknowledged that it is crucial to have a thorough understanding of the pathogen, and specific recommendations are provided in the Resource section at the end of this Chapter.

Table 1. Examples of (genus level) infectious hazards to dairy cattle. Zoonotic pathogens are indicated in red, OIE listed diseases (OIE, 2016a) are indicated with ' $(L)$ ' and the, according to the authors' opinion, more significant pathogens for dairy cattle are printed in bold. Further information regarding these pathogens can be found in the Resources section of this Chapter.

\begin{tabular}{|c|c|c|c|c|c|}
\hline $\begin{array}{l}\text { Gram } \\
\underline{\text { negative }} \\
\underline{\text { bacteria }}\end{array}$ & $\begin{array}{l}\text { Gram } \\
\text { positive } \\
\text { bacteria } \\
\end{array}$ & $\underline{\text { Viruses }}$ & $\begin{array}{l}\text { Parasites \& } \\
\text { Protozoa }\end{array}$ & Funghi & Other \\
\hline Aeromonas & Aerococcus & $\begin{array}{l}\text { Aujesky's } \\
\text { Disease (L) }\end{array}$ & Ascaris & $\begin{array}{l}\text { Trichophyto } \\
\text { n }\end{array}$ & $\begin{array}{l}\text { Prions (Bovine } \\
\text { spongiform } \\
\text { encephalopatht } \\
\text { y, L) }\end{array}$ \\
\hline $\begin{array}{l}\text { Acinetobacte } \\
r\end{array}$ & Bacillus (L) & Bluetongue (L) & Babesia (L) & $\begin{array}{l}\text { Rhinosporidi } \\
\text { a }\end{array}$ & $\begin{array}{l}\text { Mycoplasma } \\
\text { (Contagious } \\
\text { bovine } \\
\text { pleuropneumon } \\
\text { ia, L) }\end{array}$ \\
\hline $\begin{array}{l}\text { Actinobacillu } \\
\text { s }\end{array}$ & Clostridia & $\begin{array}{l}\text { Bovine Herpes } \\
\text { Virus (L) }\end{array}$ & Bunostomum & Rhizopus & Ureaplasma \\
\hline Brucella (L) & $\begin{array}{l}\text { Corynebacter } \\
\text { ia }\end{array}$ & $\begin{array}{l}\text { Bovine } \\
\text { immunodeficie } \\
\text { ncy }\end{array}$ & Cryptosporidia & Prototheca & \\
\hline $\begin{array}{l}\text { Campylobact } \\
\text { er (L) }\end{array}$ & Enterococcus & $\begin{array}{l}\text { Bovine Viral } \\
\text { Diarrhoea (L) }\end{array}$ & Dictyocaulus & Mucor & \\
\hline Citrobacta & Erysipelothrix & Corona & Eimeria & Mortierella & \\
\hline Chlamydia & Listeria & Cow pox & Fasciola & Histoplasma & \\
\hline Coliforms & Micrococcus & $\begin{array}{l}\text { Foot and } \\
\text { Mouth Disease } \\
\text { (L) }\end{array}$ & Giardia & $\begin{array}{l}\text { Entomoptho } \\
\text { ra }\end{array}$ & \\
\hline $\begin{array}{l}\text { Dichelobacte } \\
r\end{array}$ & $\begin{array}{l}\text { Mycobacteri } \\
\text { a (Bovine } \\
\text { tuberculosis, } \\
\text { L) }\end{array}$ & $\begin{array}{l}\text { Lumpy skin } \\
\text { disease (L) }\end{array}$ & Haemonchus & Candida & \\
\hline $\begin{array}{l}\text { Fusobacteriu } \\
\mathbf{m}\end{array}$ & $\begin{array}{l}\text { Staphylococc } \\
\text { us }\end{array}$ & (Para) Influenza & Ostertagia & Aspergillus & \\
\hline Haemophilus & $\begin{array}{l}\text { Streptococcu } \\
\mathrm{S}\end{array}$ & Rabies (L) & $\begin{array}{l}\text { Paramphistom } \\
\text { um }\end{array}$ & Absidia & \\
\hline
\end{tabular}




\begin{tabular}{|l|l|l|l|l|l|}
\hline Leptospira & $\begin{array}{l}\text { Respiratory } \\
\text { syncytial virus }\end{array}$ & Sarcocystis & & \\
\hline Moraxella & $\begin{array}{l}\text { Rift Valley } \\
\text { Fever (L) }\end{array}$ & Schistosoma & & \\
\hline Neisseria & Rotavirus & Stephanurus & & \\
\hline $\begin{array}{l}\text { Pasteurella } \\
\text { (Haemorrhag } \\
\text { ic } \\
\text { septicaemia, } \\
\text { N) }\end{array}$ & & Rinderpest (L) & Strongyloides & & \\
\hline Prevotella & & Schmallenberg & Toxoplasma & & \\
\hline $\begin{array}{l}\text { Rickettsia } \\
\text { (Heartwater, } \\
\text { L) }\end{array}$ & & $\begin{array}{l}\text { Vesicular } \\
\text { stomatitis }\end{array}$ & $\begin{array}{l}\text { Trichomonas } \\
\text { (L) }\end{array}$ & & \\
\hline Salmonella & Enzootic bovine & $\begin{array}{l}\text { Trypanosomas } \\
\text { (L) }\end{array}$ & & \\
\hline Treponema & & Anaplasma (L) & & \\
\hline Yersinia & & Theileria (L) & & \\
\hline $\begin{array}{l}\text { Coxiella } \\
\text { burnetii (L) }\end{array}$ & & $\begin{array}{l}\text { Echinococcus } \\
\text { (L) }\end{array}$ & & \\
\hline
\end{tabular}

In the case of each hazard, there are a number of factors affecting its release into the environment to cause harm. It is well established that cattle farms are often unique in respect to disease control (LeBlanc et al., 2006). Profound variation in release risks can be found at the level of neighbouring farms, because of different management methods present on the farm (i.e. artificial insemination versus natural mating). In the case of endemic diseases this is complicated by the fact that the release of a pathogen signifies a different risk on different farms; i.e. the release of IBR on a farm where IBR is endemically present has moderate consequences compared to the release of the same virus in a naïve herd.

Climate change, increased world trade and human travel are only some of the factors which need to be considered when identifying release risks. A consequence of the ongoing globalisation of livestock production, animal feed and food supply is that the release risk is increasingly difficult to manage (Bioportal FAO, 2011). These issues are augmented by the increasing spread of vector-borne diseases and zoonoses internationally; this is considered to be due to climate change and altered land usage along with other factors (Kilpatrick and Randolph, 2012). Table 2 lists release factors of infectious disease on a dairy farm.

Table 2. Examples of release factors of infectious disease and details of the associated release mechanisms.

\begin{tabular}{|l|l|}
\hline Release factor & Potential risks \\
\hline Livestock on site & Inadequate age separation, isolation of sick animals, cross species contact \\
\hline Livestock off site & Inadequate biosecurity of neighbours, shows, sales, markets, Al, embryos \\
\hline Machinery & $\begin{array}{l}\text { Sharing with other farms, inadequate biosecurity - vets, foot trimmers, } \\
\text { collections - tankers, fallen stock, hauliers }\end{array}$ \\
\hline Feed & $\begin{array}{l}\text { Potential contamination of feed, source of feed, feed stations - gathering of } \\
\text { stock }\end{array}$ \\
\hline Water & Shared water courses, ponds, watering holes, water stations \\
\hline Wildlife & Birds, mammals \\
\hline Humans & Zoonotic disease, contact with more than one site \\
\hline
\end{tabular}




\section{Risk assessment and evaluation}

Risk assessment is a systematic process of evaluating the potential risks that may be involved in contracting an infectious disease. The identification of hazards as sources of risk and the release mechanisms of infectious disease have been discussed in the previous section. The animal's immune system may be capable of protecting the animal against clinical disease and influence its disease susceptibility. The exposure risk for infectious agents affecting dairy cattle differs markedly throughout the world. To identify exposure, we need to focus on the role of disease detection and surveillance.

\subsection{Detection}

The OIE has promoted the rapid development of biotechnology, informatics and information systems (OIE, 2016). Biotechnology encompasses the diagnostic fields utilising materials such as nucleic acid and proteins in tests. Tests identifying specific proteins can detect antigen being present in the animal or ascertain an antibody response, indicating the animal has been exposed to the pathogen at some point. Whilst conventional methods are not to be dismissed the future is aimed at high throughput, automated systems with reduced margins of error (OIE, 2015). Techniques such as metabiomics, genomics and proteomics are developed to further our ability to identify pathogens and understand their epidemiology. Cow side tests using lateral flow technology, microarrays to screen for multiple pathogens (Shallom et al., 2011) or optical densities measured on mobile phones are all technologies being developed.

It is essential to consider the test characteristics when interpreting the results; i.e. sensitivity, specificity and predictive values (Table 3, Dufour and Hendrix, 2009). The aspiration for any test is to be $100 \%$ accurate, but this is an unachievable goal.

Table 3. Definitions important when interpreting test results.

\begin{tabular}{|l|l|}
\hline Term & Explanation \\
\hline Sensitivity & The proportion of infected animals testing positive \\
\hline Specificity & The proportion of non-infected animals testing negative \\
\hline Positive predictive value & Probability that the animal / herd is diseased, given a positive result \\
\hline Negative predictive value & $\begin{array}{l}\text { Probability that the animal / herd is not diseased, given a negative } \\
\text { result }\end{array}$ \\
\hline
\end{tabular}

The practicalities of carrying out the test may yield false-positive or false-negative results, due to reasons such as an error in reporting or cross-reaction of antibodies. The circumstances in which the test is being used is important too; the outcome of a test may depend on the stage of disease, i.e. it may take 3 weeks after exposure for an animal to have a detectable antibody response. Confidence in the sensitivity, specificity and predictive value of a test should be held up to question, particularly if anomalous results are produced. Repeating a test or using an additional test using a different methodology can improve reliability of the aggregated test outcome.

Effective sampling is as important as selecting the right kind of test. Determining the number of samples to take is dependent on the suspected prevalence of the disease (Naing et al., 2006). There is an array of formulae available within the literature to provide guidelines for sample collection (Rothmans et al., 2008). For demonstration of freedom from disease, output based surveillance can improve the efficacy of surveillance, which uses a risk-based sampling strategy (Cameron, 2012). 
Access to laboratories and diagnostic tests varies worldwide; contacting government veterinarians, universities, pharmaceutical companies or commercial diagnostic laboratories is recommended for detailed information regarding the best way forward when detecting disease in a specific part of the world. A good understanding of the disease, the farm history and the aim of testing is required to select the most appropriate test methodology.

The example farm is assessing MAP infection by means of ELISA testing. In conjunction to this, there is a national policy of skin testing in place to eradicate bTB. This is relevant, as the skin test used for bTB may produce false positive results in MAP ELISA tests for at least one month post skin testing; MAP ELISA testing would therefore not be advised in that time frame. If MAP testing within a month after bTB testing unavoidable, it is advised that positive MAP ELISA results should be confirmed by additional test methodologies, such as PCR or bacterial culture.

If we were to use a MAP antibody ELISA on milk with a sensitivity in a healthy animal of $40 \%$ and a specificity of $95 \%$, the positive predictive value of a single positive test result, if the herd has a prevalence of $10 \%$, is only $47 \%$. If the prevalence was $1 \%$ the positive predictive value would only be $8 \%$; even when specificity is high, in low prevalence herds false positives results become relatively common. Using a faecal PCR with a sensitivity of 35\% and specificity of $99 \%$ results in a positive predictive value of $80 \%$ and $26 \%$ in a $10 \%$ and $1 \%$ prevalence herd respectively. The seemingly small difference in specificity makes a large difference to the PPV in low prevalence herds.

\subsection{Surveillance}

For on-farm monitoring the recording of data and adequate interpretation is crucial in identifying whether infectious disease is present. As samples to collect for monitoring infectious diseases one should consider:

- Clinical assessment of the herd (e.g. FMD)

- (Bulk) milk samples for antigen or antibody (e.g. IBR)

- Blood samples (e.g. Leptospirosis)

- Fecal samples (individual or composite slurry) (e.g. Salmonellosis)

- Post mortem adult cattle, abattoir findings (e.g. Fasciola hepatica)

- Aborted fetus and placenta for post mortem investigation (e.g. N. caninum)

- Earnotch skin samples (e.g. BVD)

- Fertility and production performance data (to support other diagnostic findings and monitor overall herd performance)

The local diagnostic laboratory needs to be contacted for further advice on interpretation of test results as much depends on test methodology, local circumstances but also the reason for monitoring; are you aiming to control an endemic disease, or maintaining a herd free of disease? Monitoring at herd level is also important when a farm is free of disease, as historical information can help identify a possible causal relationship when positive test results are obtained.

The development and maintenance of disease surveillance programmes for infectious diseases in dairy cattle requires a robust veterinary service (Vial and Berezowski, 2015). This requires national and international input with guidance from FAO, OIE and other parties (Yassif et al., 2013). At a global level, the OIE, FAO and WHO all contribute to the Animal Health Yearbook to report the disease status of each organisations' member countries. The monitoring and exchange of disease information that is consistent, reliable and usable is vital to all countries. In the case of a zoonotic condition then the WHO is also incorporated into the process.

The evolution of a virtual surveillance network demonstrates there is a drive to deliver this surveillance using modern techniques and methods (NAHSS, 2014; UK Virtual Surveillance Network, 2011). However, even the most advanced biosecurity systems cannot negate all risk of exposure to 
disease. As well as monitoring of disease to enhance disease control efforts, surveillance data is useful for research. Surveillance is best described in terms of the three objectives it seeks to deliver: disease detection, facilitation of the response and, finally, communication of risk.

The surveillance response can manifest itself in various ways, ranging from cattle products export bans at national level to culling infected cattle, vaccination or treatment at the individual animal level. The response is dependent on the type of disease detected; a response to notifiable or reportable diseases will be decided upon by government, while in endemic diseases the response can be guided by control schemes developed by stakeholders or can be left to the individual farmer to respond to. When identifying emerging diseases, a collaboration between government and industry is helpful to support knowledge development of the pathogen involved and implement an adequate response. The delivery of an effective response is particularly challenging on a global stage. Table 4 highlights limiting factors influencing response ability at a global level.

Table 4. Limiting factors influencing international response in disease surveillance.

\begin{tabular}{|l|l|}
\hline Ranking & Factors limiting international response \\
\hline 1 & Quality of national surveillance \\
\hline 2 & Data standards for reporting \\
\hline 3 & Wildlife surveillance data \\
\hline 4 & Cooperation between international parties \\
\hline 5 & Data sharing between stakeholders \\
\hline 6 & Data storage formats \\
\hline 7 & Laboratory capability variation \\
\hline 8 & Funding for surveillance \\
\hline 9 & Training in surveillance \\
\hline
\end{tabular}

The potential benefits of robust surveillance can be seen in those Northern European countries which are officially free of several infectious diseases, including Leptospirosis, EBL, and bTB, and have strong control programs in place for MAP, IBR, BVD, Salmonellosis and Neosporosis. This tremendous achievement is largely attributed to routine practices of requesting diagnostic test results when purchasing cattle, embryos, or semen, and the use of milk-based tests for monitoring herds for diseases with substantial deleterious effects on production and longevity.

How does disease surveillance apply to our example farm?

The farm is taking quarterly bulk milk samples to monitor the herd's disease status, this provides evidence of the disease having been or being present in the herd. A positive result for IBR and Leptospirosis is worth evaluating; what is reproductive performance like in the herd, as both IBR and Leptospirosis can affect this. When the performance appears suboptimal, or when there are other drivers to undertake control (selling heifers abroad), steps can be taken to control these diseases. Continued monitoring using bulk milk is beneficial to remain informed; having access to historical data can help to explain future events, as a decrease in antibody titres for IBR or Leptospirosis would support successful control. On the other hand, a sudden rise in N. caninum antibodies coinciding with clinical abortion, would support a N. caninum diagnosis. Monitoring for government controlled diseases is minimal in the UK; bovine abortions need to be reported for Brucella surveillance and Brucella is also monitored via central bulk milk collection. The industry is promoting a BVD-free campaign and knowing this farm has been exposed to BVD previously and is currently vaccinating, it is worth discussing control measures, as participating in a national approach could be of value.

\subsection{Risk estimation and evaluation}

Risk estimation is a way to summarise the risk assessment stages; release, exposure and impact. Where quantitative data are available, risk estimation is the product of these items and can give a 
monetary value for a disease. However, where the framework of risk analysis is used on an individual farm, and numerical data are lacking, a qualitative risk estimate is still useful for each disease. This is best understood by considering specific scenarios provided in the example below.

The goal of risk evaluation is to identify what action, if any, is appropriate to mitigate the risk for a specific disease for the farm or group of cattle on the farm, region or a country in question. The result of the risk evaluation will inform the control options that are considered and subsequently implemented. There is frequently a large degree of uncertainty around risk evaluation. Efforts to quantify that uncertainty to facilitate decision making regarding further action are challenging. For example, the UK government published a quantitative risk assessment of Bluetongue virus incursion from central Europe based on weather forecasting and proximity of disease to the English Channel. Although a quantitative risk of 5-10\% for May 2016 was presented, this result did not clarify if and what control measures needed to be put in place for an individual farm (DEFRA, 2016).

At any given time a farm will be facing a number of infectious disease risks, as well as production limiting non-infectious diseases (i.e. ketosis, displaced abomasa, dystocia) and other challenges (i.e. limited feed supply, insufficient labour, trade restrictions) and the risk evaluation of a specific infectious disease will depend on ongoing other issues and the priorities of the farmer. Risk evaluation is heavily influenced by the risk behaviour of individuals involved, both farmers and their advisors. For example, one farmer may consider a potential risk (such as having cattle affected with clostridial disease) acceptable if it saves time and money, whereas another farmer may prefer to avoid this risk at all cost (and use vaccination to reduce the risk of disease). Evaluating these personal aspects is important and emphasizes the need for a tailored infectious disease control plan.

Our example herd has some evidence of IBR presence, but not Leptospirosis based on bulk milk antibody testing. The farm is embarking on an expansion programme; this has been funded by a bank loan, and the bank manager is keen to see a return on the investment in terms of more milk being sold to repay the loan. For the first time in the farmer's lifetime he needs to buy in cattle. With IBR already present in the herd, the consequences of purchasing infected cattle were considered negligible, regardless of release and exposure risk if heifers were sourced from a herd of similar health status. However, there was a lot of uncertainty in the risk estimate due to infrequent testing of bulk milk, since this only considers milking cows at a given point in time.

Given that pressure from the bank manager was more influential than pressure from the veterinarian, the farmer deemed the risk of adverse consequences due to an IBR outbreak were less of a risk than having the farm repossessed and so purchased cows at a local farm sale. However, this herd was going out of business as the farmer had become ill with persistent headaches and had been diagnosed with Leptospirosis. Testing of the bulk milk showed high titres. These were low in our example herd. Buying cattle from the infected herd was deemed to create a high risk of Leptospirosis release and exposure, with severe consequences in terms of potential litigation from staff it they became ill in addition to potential for abortions and milk drop in his herd. A vaccination programme for Leptospirosis was commenced immediately, although it was not practical to isolate and treat the incoming cattle as recommended by the veterinarian. Therefore surveillance measures were stepped up and heifer cohorts and the bull were blood sampled for serology before vaccinating. This was put in place instead of bulk milk titres, which became positive due to vaccination. An exit strategy for vaccine use was discussed, but since the neighbouring sheep grazed the fields in winter, it was decided that the disease would probably not die out completely, and vaccination would continue as long as that risk was present.

Our example farm highlights several reasons for choosing to control infectious diseases. bTB surveillance is being carried out by the government. The farmer is also relying on government border 
controls to prevent the introduction of exotic diseases from their travelling son, for example in meat contaminated with FMD from South East Asia. The surveillance for MAP is paid for by the farmer but has a clear economic incentive - to maintain the milk buyer contract. Whilst there is limited choice in whether to control these risks, the farmer is able to evaluate the risk of other diseases and decide whether they warrant control on his farm. BVD vaccination has been triggered by the detection of disease on the farm. In contrast for IBR, the farmer has evaluated the risk and chosen not to vaccinate, despite evidence of exposure being present. This decision reflects the absence of an apparent problem, resulting in a decision to save money. Finally, the risk estimation has identified Leptospirosis as a potential risk, given the herd appears to be currently naive; evaluating the risk would focus on the production and human health risks associated with this disease.

\section{Risk management}

Control options on a farm can broadly be grouped in to those where the focus is on preventing a new disease entering a farm (biosecurity), preventing further transmission of a disease already present on the farm (biocontainment) and increasing the cure rate or limiting the effects of disease (i.e. managing endemic disease).

\subsection{Preventative measures}

The complexity and rigour of the control measures as suggested in Table 5 will vary depending on for example the degree of risk reduction that is required and the resources that are available. A practical approach to reduce the risks of entry of diseases should focus on those routes of entry that are considered most likely.

Table 5. Example measures to reduce the risk of infectious disease entering a farm (biosecurity measures).

\begin{tabular}{|c|c|c|}
\hline \multirow{2}{*}{$\begin{array}{l}\text { Route of infection } \\
\text { Infected cattle on the farm }\end{array}$} & Biosecurity measure & Notes \\
\hline & $\begin{array}{l}\text { Operate a "closed" herd - } \\
\text { introduce no new cattle to the } \\
\text { farm }\end{array}$ & $\begin{array}{l}\text { This can be a very effective } \\
\text { technique but does not suit } \\
\text { all farm management } \\
\text { systems. Care needs to be } \\
\text { taken when using this } \\
\text { system that no new animals } \\
\text { are purchased including, for } \\
\text { example, a stock bull }\end{array}$ \\
\hline & $\begin{array}{l}\text { Source cattle from herd known to } \\
\text { be free of the disease in question }\end{array}$ & $\begin{array}{l}\text { When animals are } \\
\text { purchased, sourcing from a } \\
\text { herd of known status can be } \\
\text { helpful where they are } \\
\text { available. Where this is } \\
\text { carried out, ensuring the } \\
\text { (high sensitivity) testing } \\
\text { regime carried out to } \\
\text { determine the disease status } \\
\text { is appropriate is important }\end{array}$ \\
\hline & $\begin{array}{l}\text { Isolate and test any purchased } \\
\text { animals }\end{array}$ & $\begin{array}{l}\text { Quarantining incoming } \\
\text { animals is regularly } \\
\text { advocated and yet is almost } \\
\text { impossible to achieve in } \\
\text { adult dairy cows. Where } \\
\text { testing is carried out this } \\
\text { should be performed before }\end{array}$ \\
\hline
\end{tabular}




\begin{tabular}{|c|c|c|}
\hline & & purchase. \\
\hline & $\begin{array}{l}\text { Vaccinate existing and/or } \\
\text { incoming animals }\end{array}$ & $\begin{array}{l}\text { While often carried out to } \\
\text { limit the impact of disease, } \\
\text { vaccination may also be able } \\
\text { to prevent a disease } \\
\text { incursion by reducing the } \\
\text { susceptibility of animals to } \\
\text { infection }\end{array}$ \\
\hline & $\begin{array}{l}\text { Treat any animals leaving and } \\
\text { returning to the holding as new } \\
\text { animals }\end{array}$ & $\begin{array}{l}\text { Animals that are reared off } \\
\text { site or taken to livestock } \\
\text { shows must be treated as } \\
\text { incoming animals and a full } \\
\text { risk assessment carried out }\end{array}$ \\
\hline \multirow[t]{2}{*}{ Infected cattle off the farm } & $\begin{array}{l}\text { Maintain farm borders, ensure } \\
\text { double fencing to limit physical } \\
\text { contact with neighbouring cattle }\end{array}$ & $\begin{array}{l}\text { This is much easier to } \\
\text { achieve in housed cattle and } \\
\text { is not possible in all grazing } \\
\text { systems, however strategic } \\
\text { targeting of known risk areas } \\
\text { can be used. }\end{array}$ \\
\hline & $\begin{array}{l}\text { Do not spread slurry or use } \\
\text { recycled manure solids from other } \\
\text { farms }\end{array}$ & $\begin{array}{l}\text { Deliberate spreading of } \\
\text { manure from other livestock } \\
\text { can be avoided, shared } \\
\text { grazing and watercourses } \\
\text { may also represent a risk of } \\
\text { transmission of pathogens }\end{array}$ \\
\hline \multirow[t]{4}{*}{ Fomite transmission } & $\begin{array}{l}\text { Minimise the number of visitors } \\
\text { to the farm (ideally a separate } \\
\text { entrance should be provided for } \\
\text { non-farm visitors not visiting } \\
\text { livestock areas) }\end{array}$ & $\begin{array}{l}\text { There are often visitors on } \\
\text { farms, only those where } \\
\text { access to livestock areas is } \\
\text { essential should be granted } \\
\text { such access }\end{array}$ \\
\hline & $\begin{array}{l}\text { Provide suitable disinfection } \\
\text { facilities and protective clothing } \\
\text { for visitors to the farm }\end{array}$ & $\begin{array}{l}\text { This is particularly important } \\
\text { for those that will have } \\
\text { handled other livestock, for } \\
\text { example contract farm } \\
\text { workers, veterinarians and } \\
\text { relief milkers }\end{array}$ \\
\hline & $\begin{array}{l}\text { Minimise sharing of equipment } \\
\text { with other farms, disinfecting } \\
\text { thoroughly where shared } \\
\text { equipment is needed }\end{array}$ & $\begin{array}{l}\text { Not all farms will be able to } \\
\text { invest in their own } \\
\text { equipment, where } \\
\text { equipment is shared, } \\
\text { particularly equipment used } \\
\text { in livestock areas, this } \\
\text { should be thoroughly } \\
\text { disinfected. }\end{array}$ \\
\hline & $\begin{array}{l}\text { Specific areas should be available } \\
\text { for delivery vehicles and } \\
\text { disinfection facilities should be } \\
\text { available for vehicles and drivers }\end{array}$ & $\begin{array}{l}\text { Dairy farms will have high } \\
\text { numbers of vehicles visiting } \\
\text { to collect milk and deliver } \\
\text { feed amongst other thing, } \\
\text { ideally these vehicles should } \\
\text { not enter livestock areas and } \\
\text { should be disinfected }\end{array}$ \\
\hline
\end{tabular}




\begin{tabular}{|c|c|c|}
\hline Feed and water & $\begin{array}{l}\text { Feed and water quality should be } \\
\text { monitored and maintained with } \\
\text { appropriate storage }\end{array}$ & $\begin{array}{l}\text { Feed and water can become } \\
\text { contaminated with } \\
\text { infectious diseases. Care } \\
\text { should be taken when } \\
\text { sourcing feed and water and } \\
\text { control should be in place to } \\
\text { prevent contamination once } \\
\text { stored on the farm }\end{array}$ \\
\hline Other species & $\begin{array}{l}\text { Minimise exposure to wildlife and } \\
\text { other domestic animals }\end{array}$ & $\begin{array}{l}\text { Eliminating all wildlife access } \\
\text { to farms is problematic, } \\
\text { having pest control measure } \\
\text { in place and using fences, } \\
\text { raising feed trough etc. may } \\
\text { reduce the contact with } \\
\text { cattle }\end{array}$ \\
\hline
\end{tabular}

Where it is necessary to bring new animals on to a farm, determining the health status of a source herd can be challenging; methods vary from a verbal declaration by the seller through to evidence of serial testing for freedom of disease over several years. Once replacement animals have been sourced, and particularly when their health status is unknown a quarantine facility can be used. Quarantine can serve both to protect existing cattle from bought-in diseases as well as isolating new cattle from endemic diseases until vaccination has provided sufficient protection. A good understanding of the biology of the specific pathogen is essential. Quarantine of incoming cattle can be challenging when cows are lactating due to the need to use shared milking facilities. Nonlactating pregnant cattle can also pose a risk with the in utero infected foetus being a potential source of infection once born, for example for BVD. Buying youngstock, whilst not risk free, is often the most biosecure but may not meet the needs of the buyer. A comprehensive review of applying this risk assessment process to the sourcing of new dairy animals is given by Maunsell and Donovan (2008).

In many developed countries there is a stark contrast between the barrier measures taken on dairy farms compared to pig and poultry farms. Control options established in those farms can be applicable to dairy farms as well, but not as often implemented. The impact of disease exposure, small economic margins, government subsidy support, and cultural history of each industry type may explain some of the differences. The risks posed by essential visitors or borrowed machinery on a dairy farm can be reduced by the careful use of disinfectants as well as physical cleaning and good hygiene. It is essential to establish that the product used is active against the pathogens of concern (DEFRA, 2016) and manufacturers' guidelines regarding appropriate dilutions and contact times are followed. Assuring compliance is important as for example the presence of an inappropriately formulated disinfectant footbath can provide a false sense of security. It is worth noting the use of non-chemical approaches to disinfection, such as drying and or ultra-violet radiation.

As well as reducing the risk of entry of diseases on to a farm, an alternative or complementary action is to reduce the severity of the consequences of disease entry. This may be a biological strategy, for example using vaccination to limit the impact or an economic strategy such as insuring the herd against a specific disease risk. At a national level, strategies might be based on limiting the risk of further spread of the disease, for example by depopulation in cases of highly contagious diseases such as FMD.

On our example farm vaccination is being used to limit the risk of exposure. For example, the farm may not be prepared to leave the grazing bordering the neighbouring farm unused. Accepting that 
this may leave risk of exposure to BVD, the farmer has chosen to partially offset this risk by limiting the impact a disease incursion could have by vaccinating the herd.

The major risk to control is the risk of bringing disease in with either the heifers or the bull. In this instance, the farmer is not willing to change the management of the farm, therefore control measures should be put in place to limit this risk. For example, when sourcing the bull, the farmer should have bought one from a Leptospirosis free farm. If unsure about the status the purchased bull could be treated and vaccinated against Leptospirosis, even though Leptospirosis is not present on the farm. Ensuring heifers complete the herd's BVD vaccination protocol before coming onto the farm will be beneficial to protect them against diseases (sub)clinically present on the farm.

The other areas of risk are less likely sources of disease but can be controlled at relatively little cost. For example, the risk posed by the casual workers could be reduced by making them aware of the biosecurity measures to adhere to on the farm and by providing a set of boots and overalls for use on this farm only.

\subsection{Controlling the risk from existing disease}

Controlling infectious disease in dairy herds also involves the control of those diseases already present in the herd, or those diseases where prevention of entry is not achievable. In these cases the focus of control should shift to biocontainment, where steps are taken to reduce the risk of transmission of the infectious disease between animals or groups of animals in the herd. Example strategies can include separating infected animals from uninfected and susceptible animals; this can be impractical if both groups of animals are in the adult milking herd, but can be more easily achieved if, for example for MAP, the at-risk animals are youngstock and the infectious animals are adults.

Care should be taken that all potential sources of infection are identified; for example, a disinfectant footbath by the calf housing to prevent disease transmission from adult cattle to young stock may be of limited use if slurry from the adult milking herd drains through the calf accommodation. The risk of shared equipment and disease spread by staff on the farm also needs to be considered. When the preferred biocontainment measures are not possible, the next best option should be considered; for example, separate equipment for infected and susceptible animals may be preferred, but when this is not feasible, consideration should be given to appropriate disinfection of equipment.

Other options for controlling spread within a herd are either treating or culling infected animals. Where treatment eliminates the infectious organism this can form an effective means of control, for example in cattle infected with Leptospirosis, treatment with streptomycin is used to reduce the chance of subclinical renal carriage and subsequent shedding in urine. Where elimination of the pathogen from the infected cattle is not possible the infected animals can be culled from the herd, either immediately (for example with a persistently infected BVD carrier) or as part of routine culling (for example a subclinical cow infected with MAP). When these approaches are combined with good biosecurity measures, it may be possible to achieve freedom of disease.

When a reduction in risk of disease spread is unfeasible it may be prudent to tolerate presence of the disease and take steps to increase the rate of cure or limit the severity of disease. This approach can only be taken for subclinical diseases where animal welfare is not compromised. Any cattle compromised in their welfare by infectious disease should receive prompt treatment or be humanely slaughtered.

One option to increase cure and limit disease severity is to improve immune function; this can be achieved by reducing stress, providing appropriate nutrition and by breeding animals for increased 
resistance or resilience to infection (Morris, 2007; Brotherstone et al., 2010). Developments in genomics are likely to lead to further discoveries (Bishop and Woolliams, 2014; Raszeck et al, 2016).

Immunity can be stimulated by the use of vaccines. Many cattle vaccines are available, and can limit clinical signs and shedding of the infectious pathogen, or reduce the risk of infection, for example by limiting foetal infection using a BVD vaccine (Kelling, 2004). However, vaccines must be used appropriately to be effective. Vaccination regimes themselves can be complex and errors do occur, for example in maintaining the cold chain and in using multiple products at the same time (Cresswell et al., 2014). Farmer expectations about the effectiveness of vaccines needs to be carefully managed to avoid reliance on vaccination alone; whilst modern vaccines can be very effective, full protection is difficult to guarantee in the absence of any other control measures, due to poor compliance, insufficient immune response or an overwhelming challenge.

In our example herd, as discussed previously vaccination is being used to limit the potential consequences of a BVD incursion. For the diseases already present their impact within the farm also needs to be considered. In this herd MAP appears to be present but at a relatively low prevalence. In this case the goal may be maintain the low prevalence or ultimately aiming for eradication given the farmers aspirations to sell heifers internationally. In this case the biosecurity discussed above still applies, buying in a MAP positive bull would not be helpful. However, in this case, the greatest risk is the existing infected cows in the herd. The regular quarterly individual cow milk ELISAs provided a cost effective method of identifying these cows as early as possible. Then by understanding that calves at the highest risk of becoming infected with MAP, control measures can be implemented to control this risk of transmission from infected cow to calf. For example, calves born to infected dams should not be retained for breeding and positive dams should calve away from the rest of the herd. Depending on the number of cows infected, culling might be an easier way to manage the risk they pose particularly given the farmers aspirations. If this approach is implemented it would be important to warn the farmer that many more positive animals may still be present and continued monitoring would be required.

\section{Risk communication}

Communication between stakeholders is crucial in infectious disease control and is required at all stages of the control process: hazard identification, risk assessment and risk management. Most estimates of average animal disease costs in the literature have limited direct application on farm. This makes them unsuitable in our communication to farmers. Studies that quote the total cost of diseases rather than the avoidable loss exaggerate the benefits of investment in disease prevention and may thereby come to lack credibility with farmers. There is also evidence that disease costs are positively skewed thus average costs could mask the effects of rare though potentially devastating epidemics.

A different picture emerges from studies of animal disease as a source of risk to the dairy farm business. Animal disease represents a significant proportion of the risk (relating to variation in farm income) over which the dairy farmer has some control. Communication based on risk management at farm level, backed by research into the sources of variation in avoidable disease losses therefore holds promise. Budgets for interventions to control heifer mastitis were highly dependent on the farmer's willingness to pay. Knowing the risk perception of farmers and their rational spending limits would be useful for the development of specific interventions to control endemic diseases (Archer et al., 2014).

Communication science tells us that influencing behaviour is not simply a question of 'getting the message across' but of addressing the complex factors that influence an individual's behavioural decisions. There is a diversity of conceptual frameworks to help unravel the complexity of farmer 
behaviour. Data indicates the difficulties facing those designing communication strategies in a context where farmers believe strongly that they are already doing all they can reasonably be expected to do to minimise animal health risks.

A way to encourage more consistent compliance with measures might be to focus on risk communication, encouraging dairy farmers to develop a more realistic assessment of risk to their own animals. This should be tailored to the different disease risk situations faced by different farmers, which needs to involve local (public and private) veterinarians who are widely regarded by dairy farmers as the main players in interpreting and filtering information emanating from national bodies. The farming press could also be used to enhance risk communication, given the wide use and credibility of these media in the farming population.

Social science, with its emphasis on social context, has been under-utilised in the exploration of what constitutes and creates useful and valued disease risk communication (Fischhoff, 2013; Gilmour et al. 2011). Studies show that factors such as gender, education level and age influence how prevention and occurrence of disease outbreaks are perceived and best communicated. It is invaluable to make efforts to increase knowledge about disease prevention among farmers and veterinarians and for veterinarians to be encouraged to motivate farmers to strengthen farm biosecurity (Frossling and Noremark, 2016).

The importance of the role of the veterinarian is supported by Richens et al. (2015) who revealed that farmers perceive vets to have an important role in facilitating decision-making in all aspects surrounding dairy cattle vaccination. This important role was acknowledged by farmers who have regular veterinary contact, but also farmers with solely emergency veterinary contact. The individual approach to a dairy farm because of its particular characteristics is important and communication styles of different stakeholders can be hierarchical, complex and challenging (Enticott, 2008). Veterinarians' perception of their role and communication style can be at odds with farmers' reported preferences (Hall and Wapenaar, 2012).

Differences in farmers' attitudes have been shown to explain a significant degree of variance in mastitis indicators (Jansen et al., 2009) and adapting appropriately to such attitudes is key when communicating with that farmer on infectious disease control. Farmers will not act if they do not think a problem in serious enough (Jansen et al., 2010b), and this perception of 'serious' will vary between farmers. Part of this variation is due to prior information or the lack thereof. Although most farmers considered biosecurity to be important, $53 \%$ stated that a lack of information might prevent them from improving their biosecurity (Sayers et al., 2013). This lack of information and knowledge, particularly on how to adapt a particular suggestion or piece of advice is a gap that the local veterinarian can capitalize on with their particular knowledge of the farm and their infectious disease knowledge.

The credibility, of the advice itself, the perceived source of advice or the person or institution giving it is vital to the dairy farmer. The science on which recommended measures are based must be credible and clearly articulated, and the measures themselves must be seen to be realistic and costeffective. The advisor not only needs to be confident about the advice given, the adviser must also endeavour to enhance the farmers' confidence in their ability to implement the advice effectively. Training and continuing support of veterinarians and other advisors is of key importance to improve infectious disease control on farms. A mastitis control programme in the UK showed that lines of communication were important; each user received direct support from a central team, which proved to be one of the most important aspects for its success. 
A mastitis control program in The Netherlands indicated that factors describing a change in the farmers' mind-set influenced the ability to control mastitis on their farm. These factors described a change in the perceived lack of control, a change in the perceived lack of influence on sources of mastitis, and a change in their concerns about mastitis. To influence that mindset change a consistent message from different stakeholders is essential. Research shows particularly at farm level that this consistent message is often lacking; communication between advisors and veterinarians was sub-optimal with over $60 \%$ of each group not being in regular communication with each other.

With regards to the main farmer motivation for biosecurity implementation, the majority of veterinarians prioritised external factors such as 'economic benefit' and 'mandatory obligation', while the majority of advisors prioritised health/animal-related factors, which were similar to those of farmers. Inconsistencies in the implementation of and in opinions relating to, farm biosecurity were highlighted across all the groups surveyed emphasising the need for standardised evidence based information and improved communication (Sayers et al., 2014). To support a consistent message, the Countdown programme to control mastitis in Australia targets all advisor groups, and does not limit this to veterinarians only (Countdown, 2016).

Table 6 describes a range of methods that can be used to communicate infectious disease risk to farmers. Which method to use is situation dependent; a farmer is likely to be more compliant to an individual approach to their farm, however, a lack of knowledge holds some farmers back to implement changes and therefore combinations with a more general approach is appropriate in certain situations. Building a relationship with farmers to identify their mindset as well as identifying your own communication style is important and will help decide on the most appropriate communication strategy when aiming to control infectious disease on farm.

Table 6. Methods used to communicate infectious disease risk

\begin{tabular}{|l|l|l|l|}
\hline Oral & $\begin{array}{l}\text { Written } \\
\text { Electronic: }\end{array}$ & $\begin{array}{l}\text { Written } \\
\text { Post: }\end{array}$ & Social media: \\
\hline Tailored on farm & Email & Newspaper articles & Websites \\
\hline Advice from professional bodies & Government databases & Industry leaflets & Facebook \\
\hline Farmer to farmer & Text messaging & & Blog \\
\hline Conference talks & & & You tube \\
\hline Practice meetings & & & \\
\hline Webinars & & & \\
\hline (Certified) training courses & & & \\
\hline
\end{tabular}

To optimize communication on the example farm it is important to include all farm employees including family members in relevant farm meetings and training. It is advised the veterinarians adds time at appropriate routine visits to discuss disease control progress. It may help to identify relevant articles in the local farming press to align with the meetings where possible. As the farmer does attend discussion groups with peers it is important to get familiar with them; the veterinarian can discuss opportunities to contribute to those discussions if infectious diseases are discussed, or show interest in what was discussed and evaluate how it aligns with their recommendations. Farm advisors should focus on asking open questions, and be credible, i.e. follow-up areas where they are unsure about. As the farmer uses other consultants, it is important for the veterinarian to value their advice and contact them to initiate collaborations.

\section{Ensuring effective Implementation}


One beacon of successful implementation of an infectious disease control programme is that of Rinderpest. After a profound and concerted effort by affected countries, this disease was officially declared eradicated in May 2011. The demonstration that by using a cohesive and disciplined approach the desired result is achieved can be viewed as a green light to approach other infectious diseases of high impact. In the following sections different factors involved in implementation are discussed.

Studies have shown that change can be introduced on similar farms with very different results. Continuous gradual changes, previous experience with change, inner motivation, deliberate use of consultants, and careful planning have a positive impact on farming performance during and after change. A key finding is that change should be recognized as a managerial challenge and not only as a matter of implementing new technology (Hansen, 2014). The successful management of change is crucial for the survival and success of small and medium-sized enterprises, which the majority of dairy farms are. Farmers need more than experience of or knowledge about a change to be able to succeed. According to Todnem and Dale (2008), motivation is one of eight critical success factors for managing organizational change.

Problem-solving skills mean little if a farmer is not motivated to use them. A high degree of motivation is required to solve problems in unstructured contexts such as farming because solutions require repeated physical efforts. Internal motivated farmers take more actions and explore more options than farmers motivated from external forces or opportunities. Internal motivation can be influenced by communicative intervention through reasoned opinions, such as articles, study groups and discussions. External motivation can be accomplished by financial means such as bonuses and penalties related to BMSCC. Motivation rooted in inner interest is stronger and lasts longer than motivation due to external forces or opportunities.

Previous work demonstrated that 'hard to reach' farmers are not a homogeneous group, but rather could be divided into 4 categories based on their trust in external information sources and their orientation toward the outside world: 'proactivists', 'do-it-yourselfers', 'wait-and-see-ers', and 'reclusive traditionalists'. There is especially much to gain in communication with 'do-it-yourselfers' and 'wait-and-see-ers', but this demands a more proactive role on the part of veterinarians and consultants.

Different types of farmers need to be approached in different ways and through different channels to help them implement changes (Jansen et al., 2010b). For example, when aiming to improve general udder health management, the 'central route' (where tools such as instruction cards, treatment plans, checklists and software are developed in an argument-based comprehensive way and used during on-farm study group meetings for farmers organized by veterinarians and also during individual veterinarian-farmer interactions) seemed to be effective if farmers are already motivated to optimize their udder health management. For farmers who are less motivated to work on udder health, the 'peripheral route', using implicit persuasion techniques such as mass media campaigns, seemed to be most effective when aiming to change a single management practice (Jansen et al., 2010a).

Other work corroborates that farmers' attitude may be more correlated to animal disease incidence than farmers' behaviour (Kuiper et al., 2005). A study by Nyman et al. (2007) suggested that farmers' attitude towards mastitis and milk production influences the incidence rate of veterinary-treated mastitis more than environmental factors such as housing conditions. It is important to be aware of individual farmers' attitudes and goals to be able to influence change. The veterinarian is seen as the most trusted person by farmers and plays a key role as source of information for the majority of 
farmers. The relationship between farmer and veterinarian is of great importance when implementing change on farm relating to infectious disease.

Studies looking into the uptake and use of vaccines as a way to control infectious disease in cattle indicate there are often practical areas of usage of vaccines which could be improved upon. It is important to ensure a consistent approach, so all farm staff needs to be aware of and understand the animal health strategy of the farm. It is good practice to have a written procedure on how to carry out a task in a controlled and repeatable manner; it includes all requirements to carry out the task, including details of process, equipment and materials. Data collection before and after a change can provide supporting evidence towards a positive outcome and will be a motivator for some farmers to implement change. Nonetheless one needs to appreciate that without a robust and appropriate study design it is impossible to prove cause and effect.

Findings suggest that although certain biosecurity practices are undertaken to control infectious disease, many are carried out infrequently or not at all. This may be due to many factors, including cost (in time and money), lack of proven efficacy of practices and lack of relevant education of veterinarians, farmers and other herd health advisors (Brennan et al., 2012). Training, of farmers as well as veterinarians and other professionals, is a continuous process and all stakeholders should aim for continuous development to be competent to understand the reasoning behind actions.

Think about setting SMART goals when implementing change on farm:

1. Specific - use numbers or observations from the farm, e.g. reduce the incidence of clinical cases of mastitis and the BMSCC.

2. Measurable - check for improvements or deteriorations, e.g. 50 cases per 100 cows or a BMSCC of $250,000 / \mathrm{ml}$.

3. Achievable - be gradual, e.g. reduce mastitis, not eradicate.

4. Relevant - use objectives that will give you benefit, e.g. get out of the penalty band, and reduce the number of milking cow tubes used.

5. Time based - set realistic targets, e.g. over the next 12 months.

Dependent on the situation, farmers can source support from government or other stakeholder groups (levy boards, pedigree associations, retailers, milk processors) to engage the whole sector in disease control, and send out a consistent message to the industry and the general public. Considerable costs may be incurred in controlling animal diseases, though the control measures paid for may not always be effective. This is particularly true for smallholder farmers, who often lack information and have limited diagnostic data to base decisions upon.

National or regional control and eradication campaigns require financial support. Total support is often given to the control of exotic infectious diseases of major economic importance, such as FMD. Sometimes programmes are entirely funded by the farmers such as BVD eradication in Sweden (Greiser-Wilke et al., 2003). Financial support can also be given indirectly; through state laboratory diagnostic services and participation in herd health schemes. In Israel a proportion of farm insurance premiums is directed towards disease control, and in parts of Germany some costs of BVD eradication are funded from public animal insurance (Greiser-Wilke et al., 2003).

Control and eradication programmes are more effective when supported by legislation, sometimes accompanied by penalties when the legislation is contravened. For example, in Australia and New Zealand where rabies is absent, there is legislation forbidding the entry, without quarantine, of animals from countries in which the disease is present. The benefits of implementing these measures for disease control in agriculture have benefitted the consumer; bTB eradication results in milk free of bTB. The culling of infected cows however, represents a financial loss to the farmer, 
therefore control programmes can include compensation of farmers' loss of infected animals. In other situations, bonuses are offered to increase cooperation of owners; for example awarding a bonus to farmers whose bulk milk SCC is below a defined level.

How would the above relate to risk management implementation on our example farm? The scenario does not describe the motivation of the farmer in much detail, you will need to ask more questions and build a relationship with your client to identify what it is that motivates him. He is clear about his goals, and knowing he wants his herd to be as healthy as possible he is likely to be receptive to BVD eradication. The quarterly bulk milk monitoring for infectious disease is a good way to start the conversation about implementing changes to improve animal health. Presenting the nonmonetary advantages of being disease-free via accredited health schemes may motivate this farmer. He vaccinates against BVD, discuss the practicalities of when and how this happens to assess compliance and consider adequacy of the protocol. Discuss the fact that disease control is about risk reduction, and appreciate that with current farm management (grazing in summer, open sheds) it is impossible to eliminate all risk.

Identifying other stakeholders that can support you in making the changes is helpful as he is seeing various colleagues and consultants that advise him and he may otherwise be getting inconsistent advice. Report your advice briefly in writing so there is a record of what was discussed that he can refer to or discuss with others.

\section{Trends in infectious disease control strategies}

International agencies which play a crucial role in livestock infectious disease control internationally include the OIE and FAO of the UN. Their mandates enable them to operate in the international arena relatively free from political constraints. There has been increasing interaction with the WHO in recent years, partly instigated by the realisation that the majority of new human diseases originated from animals. In this context, the term 'One Health' has been used to describe the collaborative effort of multiple disciplines; working locally, nationally, and globally to attain optimal health for people, animals and the environment (Thumbi et al., 2015).

It is helpful to consider the history of disease control in the UK as described by Woods (2011) as an example when considering the input from government and other stakeholders in infectious disease control.

The highly fatal and contagious disease Rinderpest, whose ravages had prompted the 1865 formation of a State Veterinary Department in the UK, had last invaded in 1878. With the disappearance of epizootic disease, the Veterinary Department turned its attention to two endemic, widespread and costly cattle diseases that it judged to be of national importance. Bovine TB and brucellosis were of particular concern to dairy farmers and aristocratic pedigree cattle breeders, who used their political influence and social connections to lobby for state action. However, doubts surrounding diagnostic accuracy, and the time, cost and facilities required for bTB and Brucella diagnosis, meant that only a handful of livestock owners were prepared to adopt this practice. Of those that agreed to testing, many found it easier to send reacting cattle to market than to isolate them. Consequently, the tests contributed to its spread. A 1920 Order to prevent farmers presenting cows that had recently aborted for sale in markets proved unenforceable due to the difficulty in identifying them.

Another important shaping factor around state responsibility was the consumer politics of milk; a nationwide bTB programme failed to succeed, because of the low bonus offered, consumer confusion about milk grading, farmers' distrust of the state, and the unreliability of tuberculin which 
meant that by 1938 , only $3 \%$ of herds had achieved attested status. With little faith in -or money to pay for-private veterinary aid, farmers responded by slaughtering or selling sick animals and replacing them with new ones, so contributing to the spread of disease.

In November 1940, a more successful scheme for the control of certain diseases of dairy cattle (brucellosis, infertility, mastitis and MAP), commonly known as the 'survey' or 'panel' scheme was rolled out. Farmers paid a flat fee in return for quarterly visits by practising vets, at which herd health and reproductive status were assessed, advice offered and designated treatments performed. In 1952, a new organizational structure evolved-the private/public partnership of the dairy cow scheme, and had new ends in view: the education of farmers, and to prevent as well as resolve disease at the herd level.

These developments enabled the veterinary profession to build a closer relationship with farmers and the state, and to develop its expertise and reputation as 'physician of the farm'. Consequently, many veterinary practices became heavily reliant on state work, using it to subsidize their private services to farmers. Able to make an ample living from state veterinary work, drug sales and the treatment of individual sick animals, the growing body of private vets dispensed with the preventive approach of the wartime survey scheme.

This brief history of state veterinary intervention in the UK indicates that scientific knowledge and disease demographics do not by themselves explain the shifting boundaries of state responsibility for animal health, the diseases targeted and the preferred modes of intervention. Policies were shaped by concerns over food security and the public's health, the state of the national and livestock economy, the interests and expertise of the veterinary profession, and prevailing agricultural policy where 'perceptions may have more effect than the pathogens on the policies'.

Many countries are moving towards more industry-led and industry-funded control strategies, often in collaboration with government or other stakeholders but with the industry stakeholders taking the lead. To retain their disease-free status at EU or WHO level state governments need to perform surveillance to demonstrate 'freedom of disease'. Dependent on country and disease this can be done in various ways; monitoring bulk milk samples for Brucella, monitoring blood samples for Leptospirosis, monitoring slaughterhouse samples for BSE etc.

Since 1983 the National Animal Health Monitoring System (NAHMS) in the USA has been monitoring animal health across the USA. The ability to use this information as a strategic marketing advantage is at the centre of domestic and international trade competitiveness. The OIE has developed a world animal health information system to monitor and disseminate animal disease information to OIE member countries, to alert countries threatened by epidemic outbreaks, to strengthen international cooperation on animal disease control and to reduce barriers to the international trade of animal and animal products. In Europe, with the introduction of the single market in 1993, all veterinary border checks were abolished and free movement of animals became possible through the EU. Electronic identification and monitoring systems could be an especially important tool in improving collection and subsequent use of information in future animal production.

\section{Conclusion}

Infectious diseases in dairy cattle pose threats to food security, food safety, national economies, biodiversity and the rural environment. Reliance on treatment with antimicrobials is unlikely to be sustainable; therefore the control and prevention of infectious disease in dairy cattle is paramount. 
Many infectious agents can survive in the environment, and this reservoir can overwhelm host defences if hygiene is poor. We acknowledge the importance of maintaining environmental hygiene and animal immunity through adequate nutrition and husbandry, but focus on the principals of reducing the risk of infectious pathogen transmission by applying a risk analysis approach. This includes hazard identification, risk assessment, risk management and risk communication. The framework proposed in this Chapter can be applied to all infectious disease hazards in dairy cattle, and examples are provided throughout the Chapter to illustrate this point.

\section{Where to look for further information}

Infectious disease hazards in dairy cattle: http://www.oie.int/animal-health-in-the-world/oie-listeddiseases-2016/. Accessed April 2016.

Infectious disease hazards in dairy cattle: http://www.organicvet.co.uk/Cattleweb/Index.html Accessed April 2016.

Infectious disease hazards in dairy cattle: http://www.thecattlesite.com/diseaseinfo/ Accessed April 2016.

Leach, K. A., S. C. Archer, J. E. Breen, M. J. Green, I. C. Ohnstad, S. Tuer, and A. J. Bradley. 2015. Recycling manure as cow bedding: Potential benefits and risks for UK dairy farms. The Veterinary Journal 206:123-130.

Villarroel, A., Dargatz, D.A., Lane, V.M., McCluskey, B.J. and Salman, M.D., 2007. Suggested outline of potential critical control points for biosecurity and biocontainment on large dairy farms. Journal of the American Veterinary Medical Association, 230(6), pp.808-819.

Wells, S.J., 2000. Biosecurity on dairy operations: hazards and risks. Journal of dairy science, $83(10)$, pp.2380-2386.

Faust, M.A., Kinsel, M.L. and Kirkpatrick, M.A., 2001. Characterizing biosecurity, health, and culling during dairy herd expansions. Journal of dairy science, 84(4), pp.955-965.

\section{References}

Archer, S. C., F. Mc Coy, W. Wapenaar, and M. J. Green. 2013. Association between somatic cell count early in the first lactation and the lifetime milk yield of cows in Irish dairy herds. Journal of dairy science. 96:2951-2959.

Archer, S.C., Mc Coy, F., Wapenaar, W. and Green, M.J., 2014. Bayesian evaluation of budgets for endemic disease control: An example using management changes to reduce milk somatic cell count early in the first lactation of Irish dairy cows. Preventive veterinary medicine, 113(1), pp.80-87.

BioPortal FA0 2011. Challenges of animal health information systems and surveillance for animal health diseases and zoonosis. http://www.fao.org/docrep/014/i2415e/i2415e00.htm. Accessed April 2016.

Bishop, S.C. and Woolliams, J.A., 2014. Genomics and disease resistance studies in livestock. Livestock science, 166, pp.190-198.

Brennan, M.L. and Christley, R.M., 2012. Biosecurity on cattle farms: a study in north-west England. PLoS One, 7(1), p.e28139. 
Brotherstone, S., White, I.M.S., Coffey, M., Downs, S.H., Mitchell, A.P., Clifton-Hadley, R.S., More, S.J., Good, M. and Woolliams, J.A., 2010. Evidence of genetic resistance of cattle to infection with Mycobacterium bovis. Journal of dairy science, 93(3), pp.1234-1242.

Cameron, A.R., 2012. The consequences of risk-based surveillance: Developing output-based standards for surveillance to demonstrate freedom from disease. Preventive veterinary medicine, 105(4), pp.280-286.

Chi, J., VanLeeuwen, J.A., Weersink, A. and Keefe, G.P., 2002. Management factors related to seroprevalences to bovine viral-diarrhoea virus, bovine-leukosis virus, Mycobacterium avium subspecies paratuberculosis, and Neospora caninum in dairy herds in the Canadian Maritimes. Preventive veterinary medicine, 55(1), pp.57-68.

Countdown Downunder, 2016. http://www.dairyaustralia.com.au/Levy-investment/Increasing-farmprofitability-and-competitiveness/Farm-margin-improvement/Animal-performance/Managing-MilkQuality---Countdown-2020.aspx. Accessed April 2016

Cresswell, E., Brennan, M.L., Barkema, H.W. and Wapenaar, W., 2014. A questionnaire-based survey on the uptake and use of cattle vaccines in the UK. Veterinary Record Open, 1(1), p.e000042.

DEFRA, 2016. Risk assessment for Bluetongue Virus (BTV-8): risk assessment of entry into the United Kingdom-Qualitative Risk Assessment.

https://www.gov.uk/government/uploads/system/uploads/attachment_data/file/437167/qra-btveurope-201506.pdf. Accessed April 2016.

Down, P.M., Green, M.J. and Hudson, C.D., 2013. Rate of transmission: A major determinant of the cost of clinical mastitis. Journal of dairy science,96(10), pp.6301-6314.

Enticott, G. (2008) The spaces of biosecurity: prescribing and negotiating solutions to bovine tuberculosis. Environment and Planning A. 40(7): 1568-1582

FAO, Food safety through HACCP - The FAO approach, http://www.fao.org/docrep/v9723t/v9723t0e.htm. Accessed April 2016

Fischhoff, B. (2013) The sciences of science communication. Proceedings of the National Academy of Sciences. 110(Supplement 3): 14033-14039

Frössling J, Nöremark M. (2016) Differing perceptions - Swedish farmers' views of infectious disease control Veterinary Medicine and Science, 2(1);4-68

Gilmour, J., Beilin, R. and Sysak, T. (2011) Biosecurity risk and peri-urban landholders - using a stakeholder consultative approach to build a risk communication strategy. J Risk Res. 14(3): 281 295

Greiser-Wilke, I., Grummer, B. and Moennig, V., 2003. Bovine viral diarrhoea eradication and control programmes in Europe. Biologicals, 31(2), pp.113-118.

Hall, J. and Wapenaar, W., 2012. Opinions and practices of veterinarians and dairy farmers towards herd health management in the UK. Veterinary Record,170(17), pp.441-441. 
Hansen, B.G. and Jervell, A.M., 2015. Change Management in Dairy Farming. International Journal of Sociology of Agriculture and Food, 22(1), pp.23-40.

Jansen, J., Renes, R.J. and Lam, T.J.G.M., 2010a. Evaluation of two communication strategies to improve udder health management. Journal of Dairy Science, 93(2), pp.604-612.

Jansen, J., Steuten, C.D.M., Renes, R.J., Aarts, N. and Lam, T.J.G.M., 2010b. Debunking the myth of the hard-to-reach farmer: Effective communication on udder health. Journal of Dairy Science, 93(3), pp.1296-1306.

Jansen, J., Van den Borne, B.H.P., Renes, R.J., Van Schaik, G., Lam, T.J.G.M. and Leeuwis, C., 2009. Explaining mastitis incidence in Dutch dairy farming: The influence of farmers' attitudes and behaviour. Preventive Veterinary Medicine, 92(3), pp.210-223.

Kelling, C.L., 2004. Evolution of bovine viral diarrhea virus vaccines. Veterinary Clinics of North America: Food Animal Practice, 20(1), pp.115-129.

Kilpatrick, A.M. and Randolph, S.E., 2012. Drivers, dynamics, and control of emerging vector-borne zoonotic diseases. The Lancet, 380(9857), pp.1946-1955.

Kuiper, D., Jansen, J., Renes, R.J., Leeuwis, C. and Van der Zwaag, H.G., 2005, June. Social factors related to mastitis control practices: The role of dairy farmers' knowledge, attitude, values, behaviour and networks. In Proceedings of the 4th IDF International Mastitis Conference, Mastitis in Dairy Production. Current Knowledge and Future Solutions. Wageningen Academic Publishers, Wageningen (pp. 576-582).

LeBlanc, S.J., Lissemore, K.D., Kelton, D.F., Duffield, T.F. and Leslie, K.E., 2006. Major advances in disease prevention in dairy cattle. Journal of dairy science, 89(4), pp.1267-1279.

Maunsell, F. and Donovan, G.A., 2008. Biosecurity and risk management for dairy replacements. Veterinary Clinics of North America: Food Animal Practice, 24(1), pp.155-190.

Morris, C.A., 2007. A review of genetic resistance to disease in Bos taurus cattle. The Veterinary Journal, 174(3), pp.481-491.

Naing, L., Winn, T. and Rusli, B.N., 2006. Practical issues in calculating the sample size for prevalence studies. Archives of orofacial Sciences, 1(1), pp.9-14.

National Animal Health Surveillance Systems (NAHSS)

https://www.aphis.usda.gov/aphis/ourfocus/animalhealth/monitoring-and-surveillance/SA_NAHSS. Accessed April 2016.

Nyman, A.K., Ekman, T., Emanuelson, U., Gustafsson, A.H., Holtenius, K., Waller, K.P. and Sandgren, C.H., 2007. Risk factors associated with the incidence of veterinary-treated clinical mastitis in Swedish dairy herds with a high milk yield and a low prevalence of subclinical mastitis. Preventive veterinary medicine, 78(2), pp.142-160.

OIE, 2013. Guide to terrestrial animal health surveillance - OIE 23rd Edition.

http://www.oie.int/doc/ged/D13850.PDF. Accessed April 2016. 
OIE, 2016a. OIE Listed diseases, infections and infestations in force in 2016.

http://www.oie.int/animal-health-in-the-world/oie-listed-diseases-2016/ . Accessed April 2016.

OIE, 2016b. Manual of Diagnostic Tests and Vaccines for Terrestrial Animals - OIE Vol I \& II 8TH Edition. http://www.oie.int/international-standard-setting/terrestrial-manual/access-online/. Accessed April 2016.

Porter, S.R., Czaplicki, G., Mainil, J., Guattéo, R. and Saegerman, C., 2011. Q Fever: current state of knowledge and perspectives of research of a neglected zoonosis. International journal of microbiology, 2011.

Raszek, M.M., Guan, L.L. and Plastow, G.S., 2016. Use of genomic tools to improve cattle health in the context of infectious diseases. Frontiers in Genetics, 7.

Richens, I.F., Hobson-West, P., Brennan, M.L., Lowton, R., Kaler, J. and Wapenaar, W., 2015. Paper: Farmers' perception of the role of veterinary surgeons in vaccination strategies on British dairy farms. The Veterinary record, 177(18), p.465.

Roth, F., Zinsstag, J., Orkhon, D., Chimed-Ochir, G., Hutton, G., Cosivi, O., Carrin, G. and Otte, J., 2003. Human health benefits from livestock vaccination for brucellosis: case study. Bulletin of the World health Organization, 81(12), pp.867-876.

Rothman, K.J., Greenland, S. and Lash, T.L., Modern epidemiology. 2008. Philadelphia: Lippincott Williams \& Wilkins. Foundation for Alcohol Research \& Education Level, 1, p.40.

Sayers, R.G., Good, M. and Sayers, G.P., 2014. A survey of biosecurity-related practices, opinions and communications across dairy farm veterinarians and advisors. The Veterinary Journal, 200(2), pp.261-269.

Sayers, R.G., Sayers, G.P., Mee, J.F., Good, M., Bermingham, M.L., Grant, J. and Dillon, P.G., 2013. Implementing biosecurity measures on dairy farms in Ireland. The Veterinary Journal, 197(2), pp.259-267.

Shallom, S.J., Weeks, J.N., Galindo, C.L., Mclver, L., Sun, Z., McCormick, J., Adams, L.G. and Garner, H.R., 2011. A species independent universal bio-detection microarray for pathogen forensics and phylogenetic classification of unknown microorganisms. BMC microbiology, 11(1), p.132.

Thumbi, S.M., Njenga, M.K., Marsh, T.L., Noh, S., Otiang, E., Munyua, P., Ochieng, L., Ogola, E., Yoder, J., Audi, A. and Montgomery, J.M., 2015. Linking human health and livestock health: a "one-health" platform for integrated analysis of human health, livestock health, and economic welfare in livestock dependent communities. PloS one, 10(3), p.e0120761.

Tiwari, A., VanLeeuwen, J.A., Dohoo, I.R., Keefe, G.P., Haddad, J.P., Tremblay, R., Scott, H.M. and Whiting, T., 2007. Production effects of pathogens causing bovine leukosis, bovine viral diarrhea, paratuberculosis, and neosporosis. Journal of dairy science, 90(2), pp.659-669.

Tiwari, A., VanLeeuwen, J.A., Dohoo, I.R., Keefe, G.P. and Weersink, A., 2008. Estimate of the direct production losses in Canadian dairy herds with subclinical Mycobacterium avium subspecies paratuberculosis infection. Canadian Veterinary Journal, 49(6), p.569. 
Todnem, R. and Dale, C., 2008. The successful management of organisational change in tourism SMEs: initial findings in UK visitor attractions. International journal of tourism research, 10(4), pp.305-313.

UK Virtual Surveillance Network, 2011. In: A Review of the implementation of the Veterinary Surveillance Strategy (VSS).

https://www.gov.uk/government/uploads/system/uploads/attachment_data/file/456988/Virtual_S urveillance_Network_revised_March_2014.pdf. Accessed April 2016.

VanLeeuwen, J.A., Haddad, J.P., Dohoo, I.R., Keefe, G.P., Tiwari, A. and Tremblay, R., 2010.

Associations between reproductive performance and seropositivity for bovine leukemia virus, bovine viral-diarrhoea virus, Mycobacterium avium subspecies paratuberculosis, and Neospora caninum in Canadian dairy cows. Preventive veterinary medicine, 94(1), pp.54-64.

Vial, F. and Berezowski, J., 2015. A practical approach to designing syndromic surveillance systems for livestock and poultry. Preventive veterinary medicine, 120(1), pp.27-38.

Woods, A., 2011. A historical synopsis of farm animal disease and public policy in twentieth century Britain. Philosophical Transactions of the Royal Society of London B: Biological Sciences, 366(1573), pp.1943-1954.

Yassif, J, Santhakumar, A and Lightfoot, N, 2013. Enhancing Global Security through Infectious Disease Threat Reduction - Global Health Security.

https://www.chathamhouse.org/sites/files/chathamhouse/public/Research/Global\%20Health/0713 pp_infectiousdiseasereduction1.pdf. Accessed April 2016.

Zinsstag, J., Roth, F., Orkhon, D., Chimed-Ochir, G., Nansalmaa, M., Kolar, J. and Vounatsou, P., 2005. A model of animal-human brucellosis transmission in Mongolia. Preventive veterinary medicine, 69(1), pp.77-95. 